\title{
Combining Digital and Traditional Representation Techniques to Promote Everyday Cultural Landscapes
}

Marco Vedoà

\section{Abstract}

The paper deepens the opportunities and the issues of cultural landscape education with ICTs in pandemic situations. The global emergency and the new social distancing rules have changed the didactic approach at any level. Cultural Landscape Education has been affected as it needs the direct experience of places and the direct involvement with local citizens. In this scenario, the involvement of digital representation tools (i.e., webGIS, web maps, interactive storytelling, geogames, and virtual and augmented reality) may offer useful alternatives for students and teachers. The School Activates Resources research project (Scuola Attiva Risorse) suggested, two years before the pandemic, the involvement of digital tools for the cultural landscape education in schools. This experience has allowed setting an online task with students of the course 'Fundamentals of Representation' at Politecnico di Milano during the academic year 2020-202I. The task aimed at combining traditional and digital techniques and offering students the opportunity to develop skills in sketching and the use of digital representation tools. Moreover, the task offered students experiment independently with alternative advanced techniques such as photo merging, photo insertion, and panoramic photo captures.

non-outstanding cultural landscape, cultural landscape education, digital storytelling, virtual reality, interactive representations.

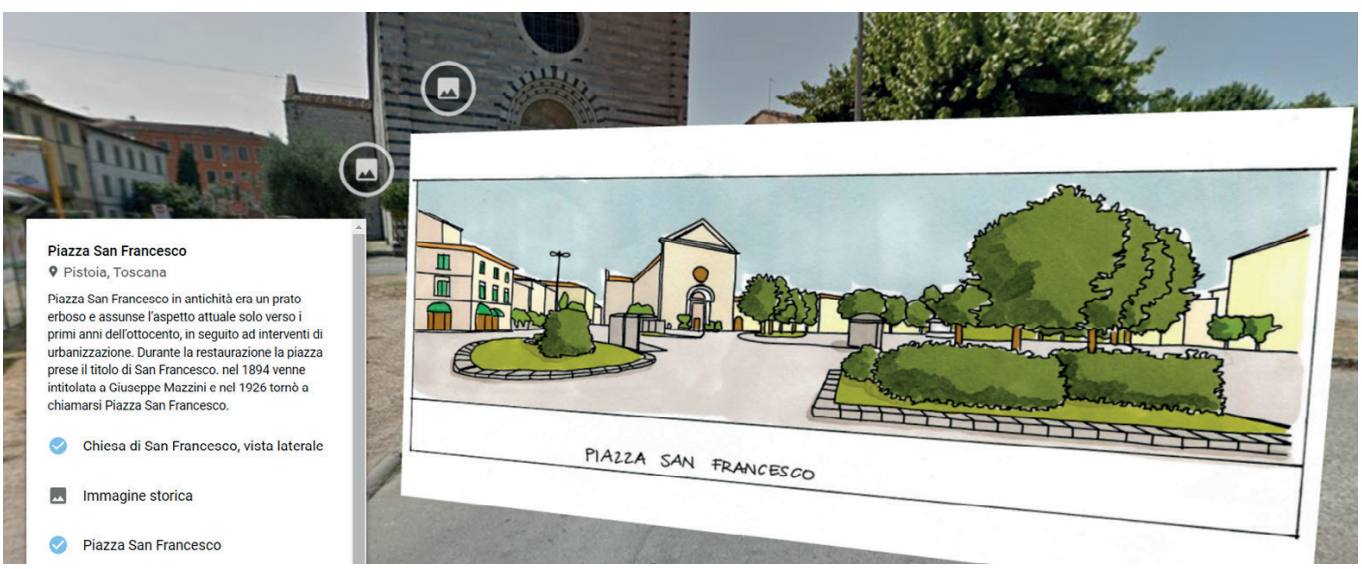


The 2020 and 2021 global emergency has suddenly modified the didactic approach at any learning level.Teaching has had to move from physical to virtual environments changing the interaction between teachers and students. Online lessons and laboratories have forced the digitization of the activities and relationships. This scenario pushed to rethink tasks usually performed in class, especially those performed on the field. Cultural landscape education involves the direct experience in the place, and the processes experimented in the past should have been adapted to the new situation.

European and Italian documents highlight the importance of cultural landscape education in schools. The Faro Convention [Council of Europe 2005] and the European Recommendation R (98) n. 5 on the education to the members States highlight the right to citizens to be part of the cultural activities and the importance to set an educational approach based on the tangible and intangible actions of the humankind on the territory. At the Italian level, the heritage education plan [MIBACT 20I9] considers these processes the contributors to improve the local cultural and social aspects. Similarly, the National Plan for the Digital School [MIUR 20I5] pushes the development of didactic processes to enhance cultural heritage with advanced digital tools. These documents match with the principle, and the recommendations suggested in the European Landscape Convention [Council of Europe 2000] and the Carta Nazionale del Paesaggio -National Landscape Chart- [MIBACT 20I8] which remark the importance of building a "landscape awareness", especially from schools. Moreover, the documents highlight the extension of the enhancement action on the entire territory, integrating the definition of outstanding cultural landscape suggested by Unesco [AUTORE 2012]. Hence, cultural landscape education should also focus on the entire territory and especially on the "everyday" and "degraded" non-outstanding landscapes [Salerno 20 I8; Sodano 20l7] as suggested on the European Landscape Convention [Council of Europe 2000]. Finally, the involvement of advanced representation tools offers to promote and experience non-outstanding landscapes otherwise hidden and give students editorial, organizational, and advanced IT skills [Di Blas 2012; Ippoliti 2011; Ott 201 I].

Involving digital tools in non-outstanding cultural landscape education was one of the main topics experimented with during the research project School Activates Resources, Scuola Attiva Risorse - ScAR (<http://www.scar.polimi.it>). The project, winner of the Polisocial Award 2017 at Politecnico di Milano and funded by the tax donations (5perMille), aimed at developing a cultural landscape education process in which schools are the main actors and promoters of the everyday cultural landscape. The research focused on the southern suburban areas of Milan which depict several social, environmental, and economic fragility aspects. One of the main activity of ScAR was involving students in developing a participatory process for communicating and enhancing the cultural landscape with digital applications such as virtual reality, interactive maps, tourist guides, and urban geogames.

Students were pushed to experiment with traditional representation techniques such as mental mapping, live sketching, and modelling to narrate their neighborhood and the home-school route; and then with advanced visualization tools, such as interactive maps, virtual reality applications, and web GIS. To build the local knowledge and develop contents on the history, the traditions and the human geography of the area, students performed documentary research in libraries and interviews with locals (parents, associations, and shopkeepers). Moreover, the research team accompanied participants on outdoor learning tours to explore their everyday landscape. During this task, participants were pushed to experiment with a map, draw the route, and visit the landmarks. Then students were involved in developing advanced representation tools to allow external users to learn the local cultural landscape. The research team individuated several digital free web applications: Izi.travel, for the development of open and interactive mobile tourist guides; JuxtaposeJS for developing an image comparison app; StoryMapJS to create interactive storytelling based on a map; and Google Tour Creator for the development of interactive virtual reality tours. Moreover, ScAR collaborated with GaiaSmart [Carli 2017] to build two interactive geogames. With MUMI - Ecomuseo Sud Milano which developed the geoblog Atlante Digitale Delle Memorie (the Digital Atlas of Memo- 
Fig. I. Lo sbaglio della Conca. The storytelling developed with StoryMapJS by the students of the middle school students in Milan.
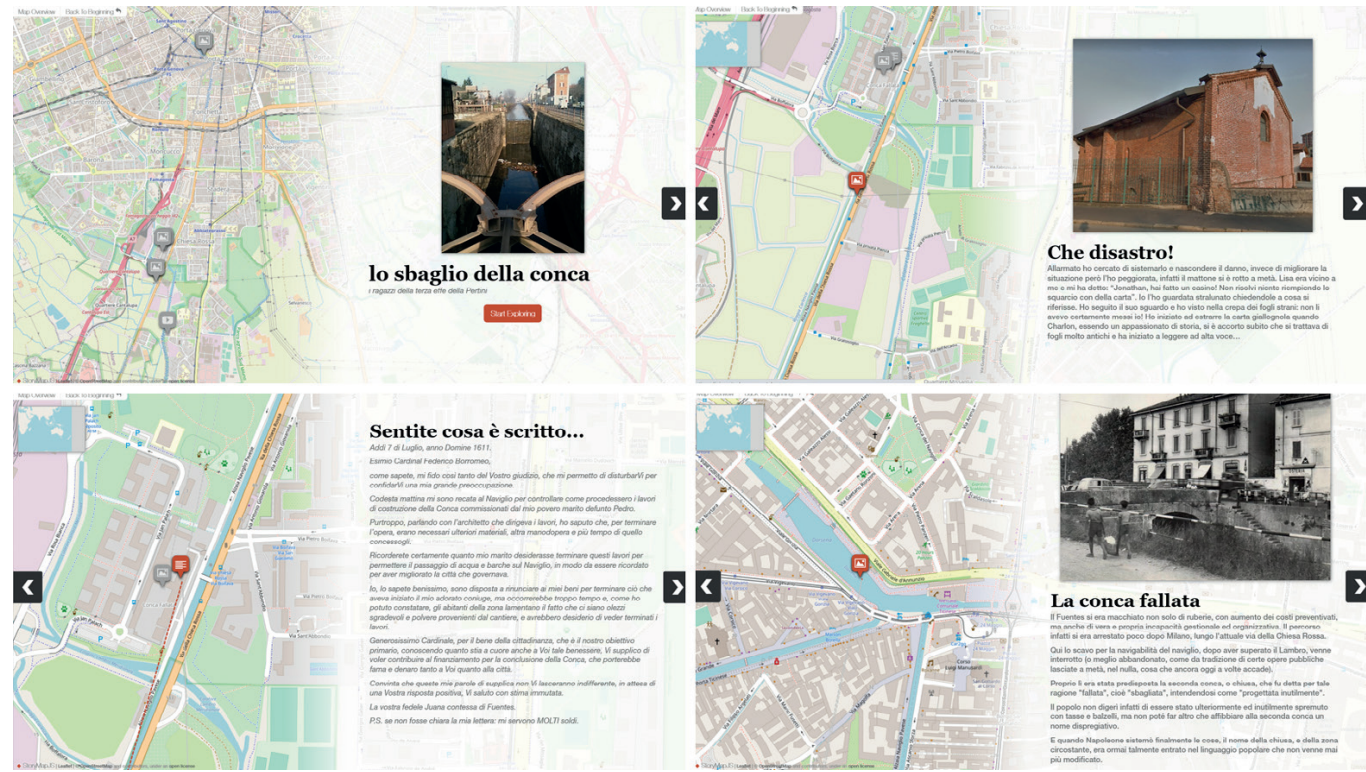

Che disastro!

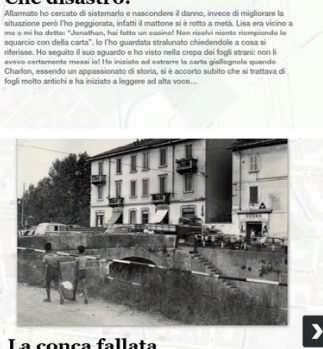

$\mathbf{r}$

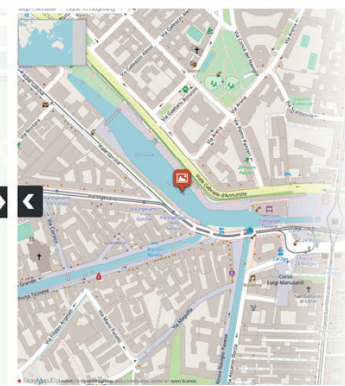

La conca fallata .

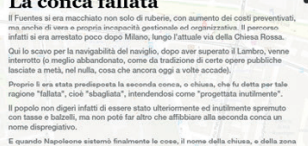

ries) for gathering information, documents, and media of the southern suburbs of Milan. The team chose these applications according to several features: the easy back end to develop complex storytelling; the opportunity to upload different media (images, documents, videos, and audio files); the open license that allows users build their storytelling for free; and the presence or the opportunity to share for free the products. After initial training delivered both to students and teachers, the research team accompanied participants to develop interactive applications. The aim was to involve students in using new ITCs, learn the value and features of the everyday landscape, and build a stronger local identity [Copeland 2006].

Two interesting applications, StoryMap/S and Google Tour Creator, allowed participants to build interactive storytelling of the local cultural landscape, which were further enriched with images, sounds, and videos. StoryMapJS is a free open source software (FOSS) that allows users to build interactive routes based on a map. The route consists of several steps in which the creators can add an image, links to external resources (webpages, videos, audio files, and documents), and a written description. The result is an enriched storytelling that developers can share with other users. Students from the primary and middle schools produced several applications to tell the story of particular elements and landmarks of the area or tell their diary route to school (fig. I). The application's feature to upload media and external resources allowed participants to customize the route with photos, historical images, music video clips, and drawings. Hence, the storytelling became a subjective representation of the everyday landscape that communicate landmarks, places, and perception from the young citizens' perspective [Bonfantini 2019].

Google Tour Creator is a web application for developing educational virtual reality experiences. The application is free and offers an open platform to share the users' virtual tours. The back end allows users to create virtual scenes from personal spherical images or the Google Street View archive. Additionally, the Street View mobile application features Cardboard Camera app with which users can take panoramic and $360^{\circ}$ photos and then upload them to the scene. The spherical images work as the background of the scenes on which is possible to add an ambient audio file and to pin interactive point of interests. The pins can be placed onto the virtual spherical image's surface, and into them, users can add a description, an image, and an audio file. In collaboration with high-school students, the research team developed a prototype, a virtual reality tour to explore the Milan southern suburbs cultural landscape, and to learn the history of the place. The prototype Experience Tour del Quartiere Stadera -Experience Tour of Stadera 
Fig. 2. Experience tour del Quartiere Stadera.Th prototype developed with Google our Creator by the research team in collaboration with high school students.
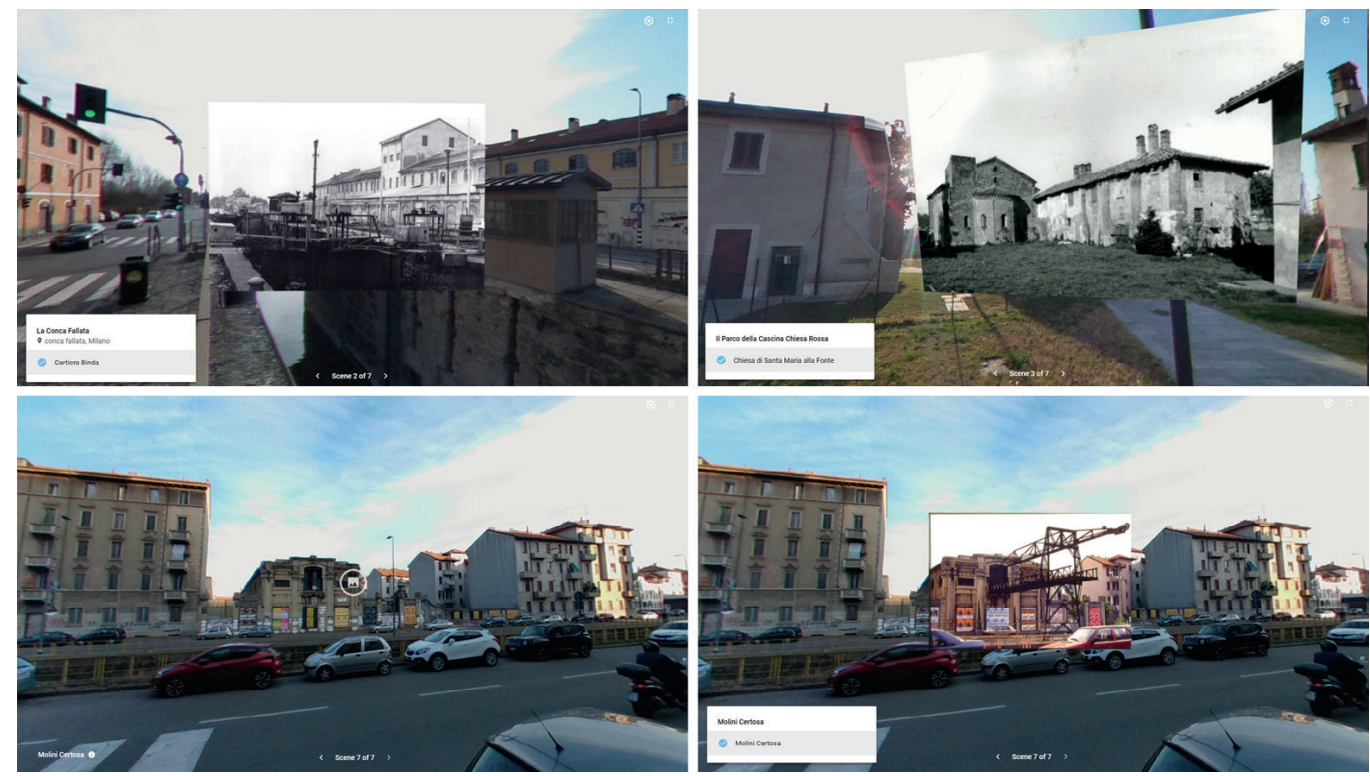

Neighborhood- is a virtual experience with seven scenes in which users can experience the place and interact with several points of interests (fig. 2). The pins trigger an audio guide that tells the history of the building or the place and show a historical image. This image overlaps the background photo to learn how the site has been evolving along with history. The research team then released the prototype on the sharing platform 'Google Expeditions' on which users can perform the virtual tour from the desktop version -the virtual tour can be explored directly from the browser- and from the mobile application. In this way users can also experience the tour with virtual reality goggles (i.e., Google Card Board). This feature offers a further opportunity for VR applications in schools because this kind of goggles is cheaper than standalone systems. The research team finally tested the application during several events with different age and IT skills users [Casonato 2020; Bertone 2019].

During the ScAR project, the experience showed the possibility of involving advanced digital tools in didactic processes, especially in those devoted to teaching the representation techniques. The course of 'Fundamental of Representation', delivered by professor Camilla Casonato, at Politecnico di Milano aims at giving students the analogue and digital tools and the techniques for representing the architectonic, urban and territorial spaces. Besides the principle of the projective and descriptive geometry, the course suggests developing a diary sketchbook in which students are pushed to draw spaces, architectures and objects according to the lessons delivered. This task used to be accompanied with an outdoor survey campaign where students were asked to represent the plan, the section, the façade, and a couple of perspective views of a part of an architecture. According to the social distancing rules, the campaign was canceled and replaced with a remote and interactive task that allowed students to keep the opportunity to apply the contents delivered, improve their sketching skills, and develop skills in using innovative applications. The ScAR experimentations have given the opportunity to learn the potential of digital tools in the cultural landscape education and introduce students in the use of advanced representation technologies. In this perspective, during the academic year 2020-202I the course suggested the implementation of Google Tour Creator and StoryMap/S to offer students the opportunity to match traditional representation techniques with advanced digital tools. The aim was to push students to develop interactive storytelling of their everyday landscape through live sketching. The sanitary emergency made risky the work in presence and the organization of a collective survey and live sketching campaign like past years. In response to that, the task was modified and performed independently by students in their home towns. Students were assigned 
Fig. 3. Scenes from the interactive tour of Quartiere Risorgimento in Milan developed with StoryMap|S. The student also experimented with the photo insertion of the sketches (graphic elaboration by Lidia Spaventa). to develop a diary in which sketching architectures, places, landscapes, details, and maps of their home town and neighborhood. Students were further asked to create a virtual tour with Google Tour Creator or a StoryMapJS interactive route in which upload a selection of their sketches.

The interactive routes developed with StoryMapJS consist of a first presentation slide in which students describe with a map or a sketch the place. The next georeferenced steps present landmarks and places with photos, historical images, sketches and a short description. The aim was to push students towards an interpretation of the places through drawing and highlight buildings, features, and details of their everyday landscape (fig. 3). Similarly, the virtual tour developed with Google Tour Creator aimed at developing an interactive experience in which the virtual scene works as the background on which students pinned sketches, historical images, and audio files of the local cultural landscape (figs. 4-8). Moreover, for the development of the virtual tour students were trained in StreetView Camera, which allows users to take spherical images that can be uploaded as the background of the scenes.
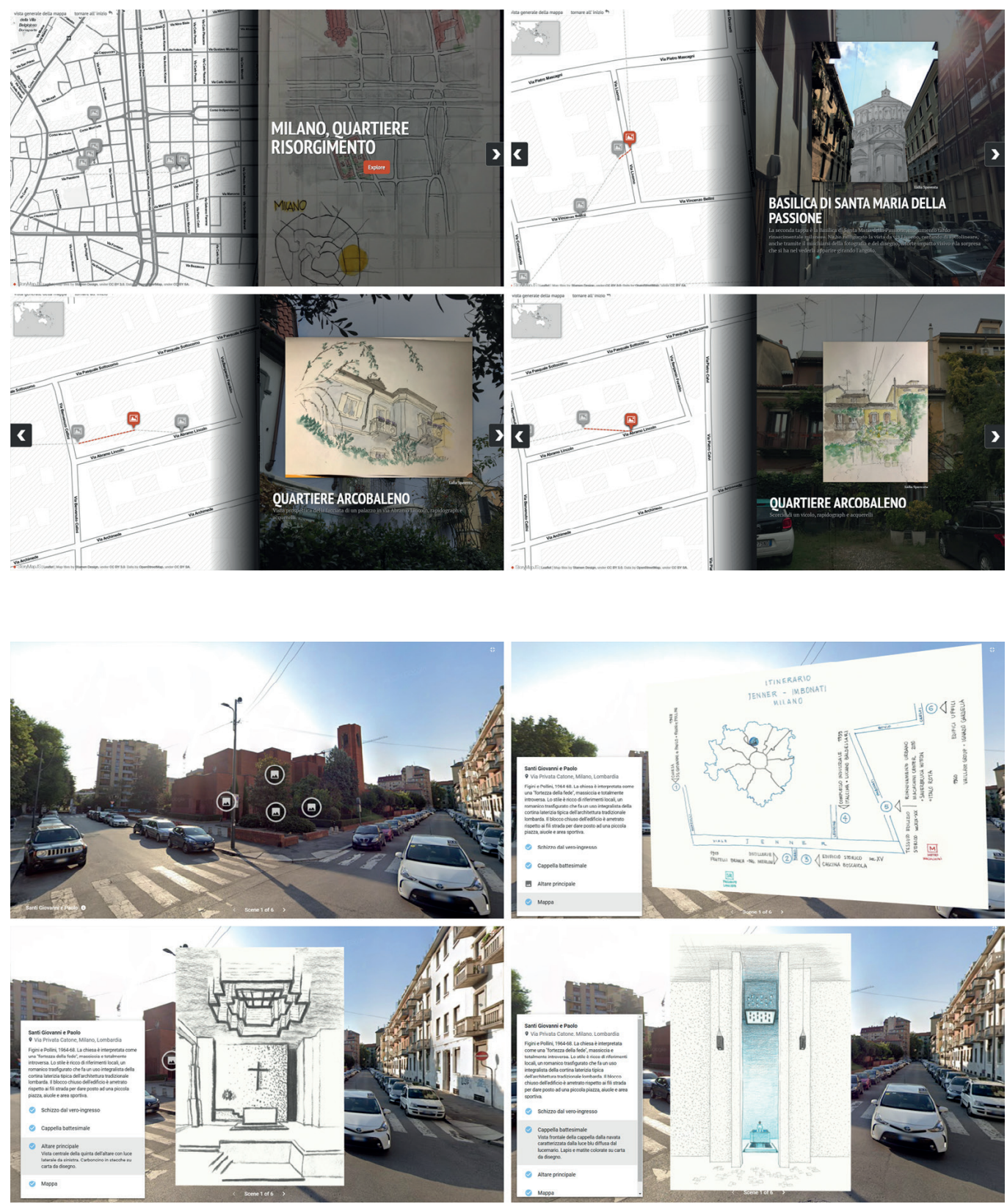

Fig. 4. Scenes from the virtual reality tour of Dergano neighborhood in Milan (graphic elaboration by Marco Spiga) 
The task gathered the interest of students. Combining traditional techniques and innovative digital tools pushed students to experiment with advanced techniques (i.e., photo merging, photomontage, and photo insertion) to customize their storytelling (fig. 3). In this direction, a student suggested a mixed application to take advantage from the two digital tools. The student integrated into the StoryMapJS steps several links to Google Tour Creator scenes to georeference the scenes and base the work on an interactive map (fig. 9).

In November 2020 Google announced the close of Google Tour Creator and Expeditions, the sharing platform, for June 202I. To preserve the contents and facilitate the evaluation process, students were asked to create a short video clip (up to two minutes) of their virtual tours, which were presented during the final evaluation online seminar. The evaluation was based on two criteria: the quality of the sketches and of the tours, and on the progressive improvement of the traditional and advanced techniques learnt during the course.

Fig. 5. Scenes from the virtual reality tour of Pistoia (graphic elaboration by Elisa Sorcinelli).

Fig. 6. Scenes from the virtual reality tour of Fossalta di Portogruaro (graphic elaboration by Elia Villotta).
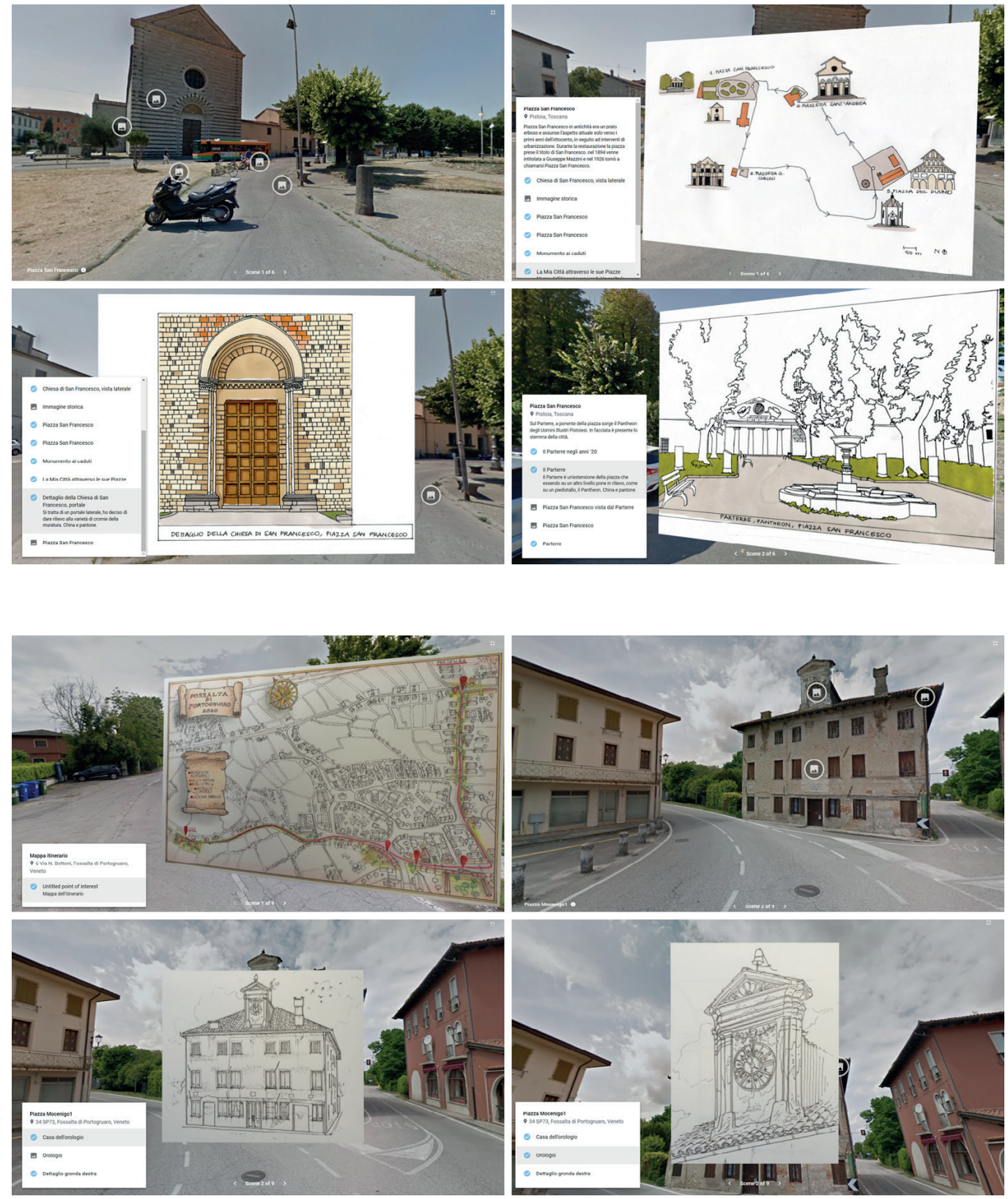
Fig. 7. Scenes from the virtual tour of Monza (graphic elaboration by Alice Vergani).
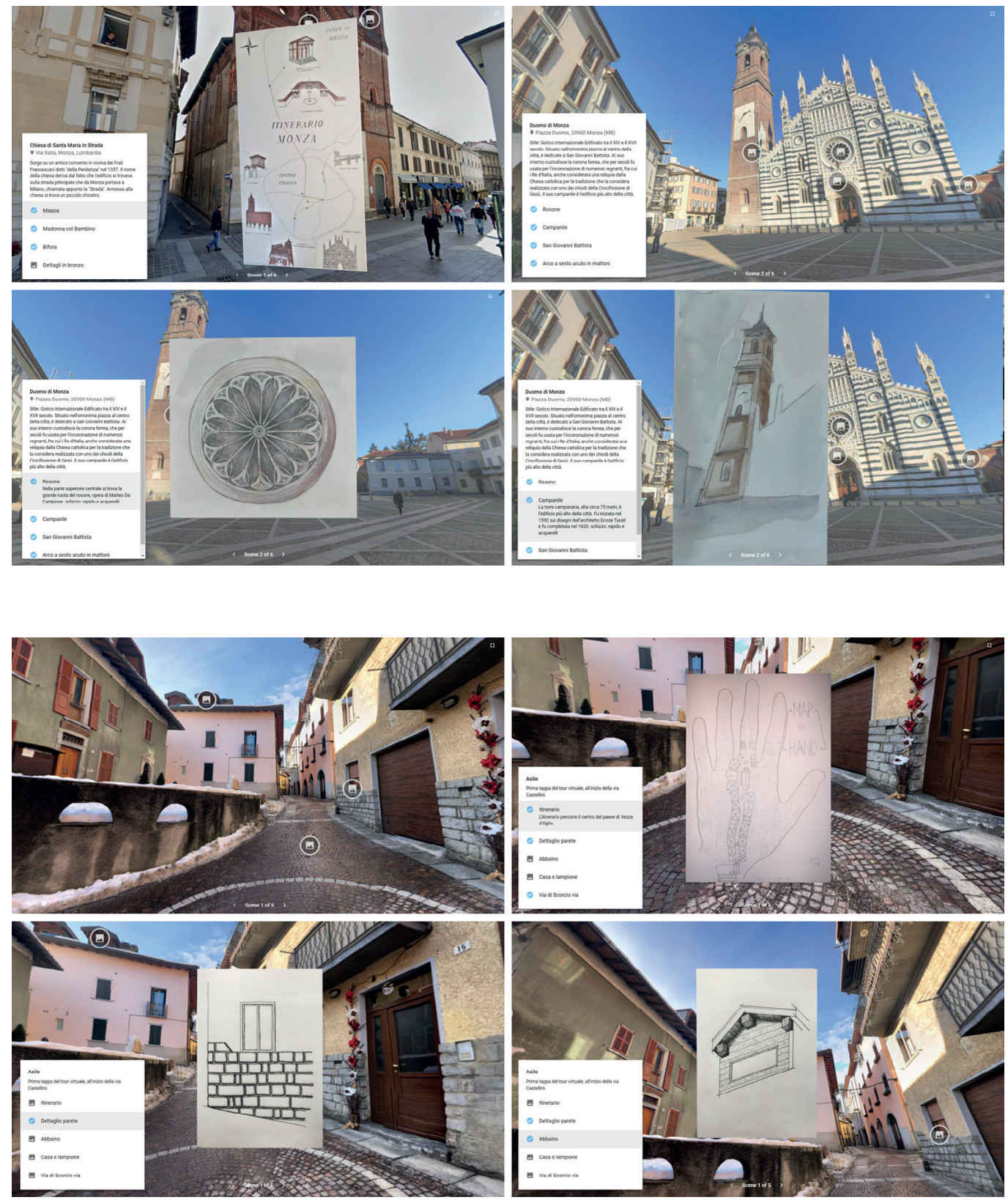

\section{Conclusions}

The integration of traditional and advanced representation tools has shown several opportunities, whether they are performed in schools or in a university course. As seen during the ScAR project and the course of 'Fundamentals of Representation', the approach matched students' interest in the analogical tasks -the sketching and survey campaign- and in the use of digital tools. The experimentation with other advanced representation techniques (i.e., photomontage, and photo insertion) and adapting the tools to the students' needs suggest their will to enrich their skills in this field. The task also contributed to overcoming the distance between students. The lessons and the seminars on the use of the digital tools generated interaction among and with them. The most engaged students also helped others in the development of the tours. Moreover, the experience offered to enlarge the survey campaign field, which was usually limited to the urban context. In this perspective, the task has shown the opportunity to promote the everyday landscape in 
didactic processes which is performed in two directions: for students that develop the digital storytelling because they are pushed to look at their everyday landscape with a critic eye; and for external users which can explore places usually not considered as outstanding landscape. However, the task showed critical aspects. The interaction with students was justifiably limited and not fully reached. Social distancing did not allow tutoring students during the survey campaign like past years but only with online and periodical reviews. Concerning digital tools per se there are two aspects to consider. Applications are frequently ephemeral, especially the FOSS, and they are under the decision of the producers or the developers' community. The announce of Google to shut down Tour Creator and Expedition applications by July 2021 is a clear example. Moreover, the rapid evolution of technology makes obsolete tools and services in few years or even months and forces the constant updating of tools and techniques.

Fig. 9. Scenes from the interactive tour of Milan with the integration of the virtual reality scenes (graphic elaboration by Gaia Terranova).

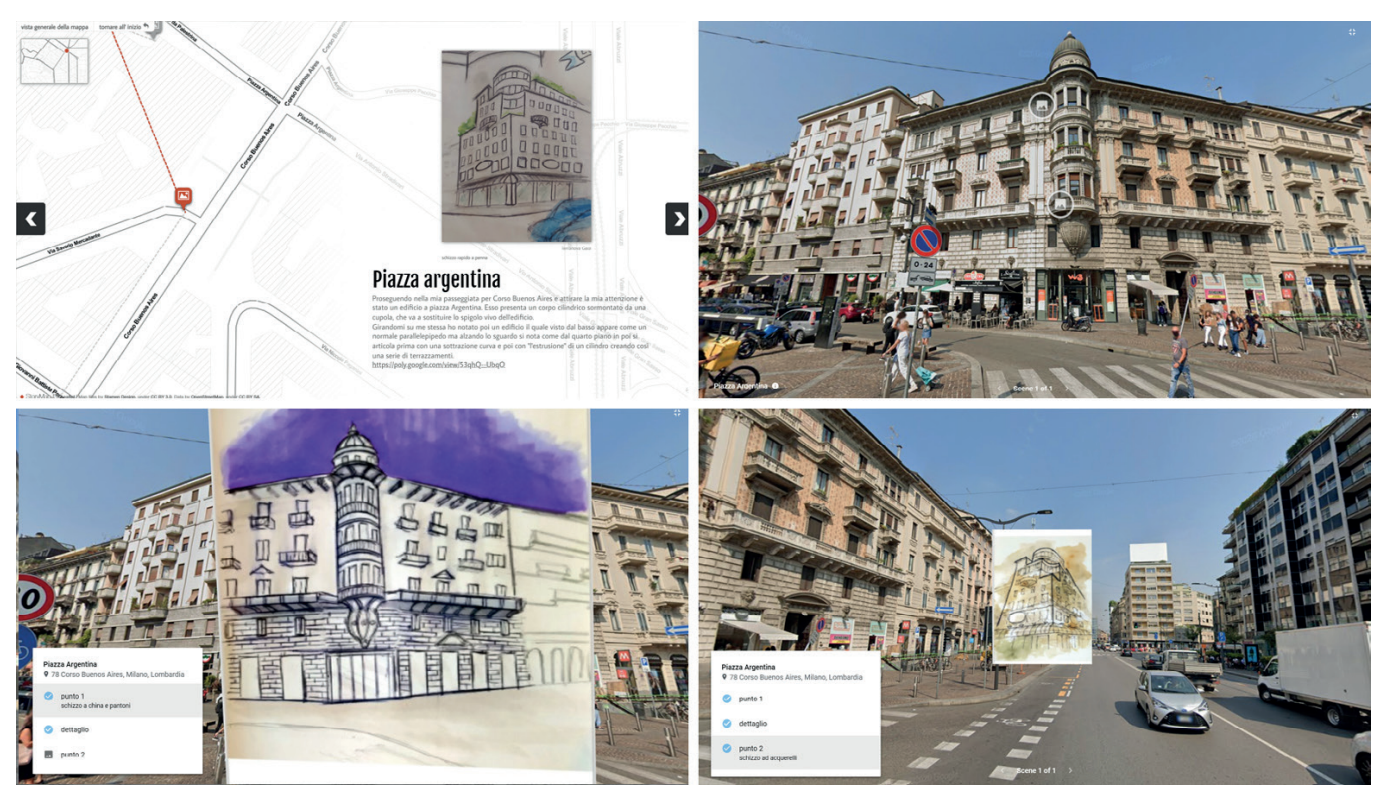

\section{References}

Bertone G. et al. (2019). Schools as Protagonists in the Valorization and Communication of their Local Cultural Heritage. In J. Theo Bastiaens (Ed.). Proceedings of EdMedia + Innovate Learning, pp. I562- I568. Amsterdam, Netherlands: Association for the Advancement of Computing in Education (AACE). Retrieved November 25, 2019. <https://www.learntechlib.org/primary/p/210175/> (accessed 2021, February 20).

Bonfantini B. et al. (2019). Revealing the everyday landscape: innovative systems for heritage education in schools. The scar (school activates resources) project. In Proceedings of the GEORES (Geomatics and Restoration). Conference 20 I9, Milan, May 8-10. ISPRS International Archives of Photogrammetry, Remote Sensing and Spatial Information Sciences.

Carli P. (2017). GAIAsmart. Un'app ICT georeferenziata per la disseminazione e lo storytelling del patrimonio culturale/ GAIAsmart. A free georeferenced ICT app for the dissemination and the storytelling of the cultural heritage. In Villa D. (Ed.). Open Data for Cultural Heritage, Place Based Digital Humanities Between Representation, Design and Innovation. Planum: Milan, pp. 55-62.

Casonato C. Greppi A., Vedoà M. (2020). Depicting the Urban Landscape. Enhancing the Cultural Heritage of Fragile Areas with Participatory Mapping Processes. In (Eds.). Agustín-Hernández L., Vallespín A., Fernández-Morales A. Graphical Heritage Mapping, Cartography and Innovation in Education, vol. 3, pp. 295-306. Charm (CH): Springer.

Copeland T. (2006). European democratic citizenship, heritage education and identity. Strasbourg: Council of Europe Publishing.

Council of Europe (2000). Convenzione europea del paesaggio. In Congresso dei poteri locali e regionali del Consiglio d'Europa, Firenze.

Council of Europe (2005). Faro Convention. Council of Europe Framework Convention on the Value of Cultural Heritage for Society. Faro, Portugal.

Di Blas N., Paolini P., Sabiescu A.G. (20I2). Collective digital storytelling at school: a whole-class interaction. In International Journal of Arts and Technology, vol. 5 (2-4), pp. 27 I-292. 
Ippoliti E., (20I I). Digital Media and enjoyment of Cultural Heritage. In DisegnareCon, n.4(8), pp. 2-13.<https://disegnarecon. unibo.it/issue/view/276> (accessed 202I, February 20).

MiBACT (Ministero per i beni e le attività culturali e per il turismo)(20 I8). Carta Nazionale del Paesaggio. Elementi per una strategia per il paesaggio italiano. Roma: Gangemi Editore.

Ministero dell'Istruzione Università e Ricerca MIUR (2015). Piano Nazionale Scuola Digitale.

Ministero per i Beni e le Attività Culturali e per il Turismo MiBACT (2019). Note per l'educazione al patrimonio culturale.

Ott M., Pozzi F. (20I I).Towards a new era for Cultural Heritage Education. Discussing the role of ICT. In Computers in Human Behavior, n. 27, pp. 1365-137I. Washington, USA: America Psychological Association.

Salerno R. (20 8). Enhancing Not-Outstanding Cultural Landscapes in a European Perspective: A Challenge for Digitization. In Amoruso G. (Ed.). Putting Tradition into Practice: Heritage, Place and design, pp. 3-8. Charm (CH): Springer International.

Sodano C. (2017). Cultural Landscapes in International Charters. In Museum International, n. 69, pp. 80-85. <http://www. icom-italia.org/wp-content/uploads/20 I8/02/ICOMItalia.MuseumInternational.Articolo.CeciliaSodano.pdf> (accessed 202I, February 20).

UNESCO (2012). Operational Guidelines for the Implementation of the World Heritage Convention. UNESCO World Heritage Centre, Paris.

Author

Marco Vedoà, Politecnico di Milano, marco.vedoa@polimi.it

To cite this chapter. Vedoà Marco (2021). Combining Digital and Traditional Representation Techniques to Promote Everyday Cultural Landscapes. In Arena A., Arena M., Mediati D., Raffa P. (a cura di). Connettere. Un disegno per annodare e tessere. Linguaggi Distanze Tecnologie. Atti del $42^{\circ}$ Convegno Internazionale dei Docenti delle Discipline della Rappresentazione/Connecting. Drawing for weaving relationship. Languages Distances Technologies. Proceedings of the 42th International Conference of Representation Disciplines Teachers. Milano: FrancoAngeli, pp. 2677-2685. 